\title{
DNA Damage in Workers Occupationally Exposed to Lead, Using Comet Assay
}

\author{
P.Manikantan, V.Balachandar \& K. Sasikala \\ Division of Human Molecular Genetics, Department of Zoology \\ School of Life Sciences, Bharathiar University \\ Coimbatore, Tamilnadu 641046, India \\ E-mail: humangentistmani@gmail.com
}

\begin{abstract}
Lead is one of the most clinically important heavy metals, because it induces a broad range of physiological, biochemical, and genetical dysfunctions. Occupational exposure to lead leads to increased frequency of genetic system in human beings. In the present study the DNA damage among the workers occupationally exposed to lead was analyzed using peripheral blood lymphocyte by comet assay. The result of this study shows increased levels of DNA damage among experimental subjects. The habit of cigarette smoking among the workers has a synergistic effect on inducing DNA damage.
\end{abstract}

Keywords: Lead exposure, Comet assay, DNA damage, smoking

\section{Introduction}

Mutagenesis is involved in the pathogenesis of many neoplasias. Occupational exposure may contribute to the development of pernicious illnesses, many times through mechanisms that involve genetical changes. In order to evaluate the possible impact of environmental and occupational exposition on health, it is essential to identify the effects of exposure through epidemiological studies.

Continuous efforts have been made to identify genotoxic agents, to determine conditions of harmful exposition and to monitor populations that are excessively exposed (Maluf and Erdtmann, 2000).

Lead $(\mathrm{Pb})$ is an abundant, globally well-distributed, dangerous and important environmental chemical. Pb has been found to be capable of eliciting a positive response in an extraordinarily wide range of biological and biochemical test, which include the tests for enzyme inhibition, fidelity of DNA synthesis, mutation dislocation, chromosome aberrations, cancer and birth defects (Johnson, 1998). Determination of blood lead concentration is a widely accepted biological marker of exposure to lead (Lanphear et al., 2000; Mielzyn'ska et al., 2001). Also the cytogenetic studies in workers occupationally exposed to $\mathrm{Pb}$ produced inconsistent results (Johnson, 1998). Recently, the results of some in vitro and in vivo tests detecting the genotoxic effects of $\mathrm{Pb}$ have been reported (Vaglenov et al., 2001). In other in vivo study, significant increase in mean tail length of DNA was observed at all time intervals after treatment with $\mathrm{Pb}$ nitrate when compared to control (Devi et al., 2000).

During the last few years, there has been a great interest in developing, rapid and simple tests to identify the effects of exposure to environmental agents that can affect the health of individuals due to DNA damage. In this observe, present study considered whether individuals working with $\mathrm{Pb}$ exposure more DNA damage with the increase in the exposure period and smoking habits using by the Comet assay also known as single cell gel electrophoresis (SCGE) and it is a very sensitive method for measuring DNA damage (Singh et al., 1988).

Therefore the focal aim of present study was DNA damage in peripheral blood lymphocytes it can be used as a biomarker of health outcome, measuring genetic damage due to exposure that results from non-repaired primary lesions in $\mathrm{Pb}$ exposure. Although $\mathrm{Pb}$ exposure has been extensively investigated, to the greatest of our knowledge, this is the first to perform a Genetic study in this region.

\section{Material and methods}

\subsection{Demographic profile of selected area}

Coimbatore, the Manchester of South India is located in the western region of Tamilnadu, bordered by the panaromic Western Ghats. The total population of the Coimbatore district is 42.25 lakhs $(21,56,280$ males and 20, 67,817 females). 
Due to the existence and predominance of population the silent toll of human lives due to numerous diseases is on the rise.

\subsection{Subject Recruitment and Sample Collection}

The study was conducted on 30 male (83.33\%) and female (16.67\%) workers aged 20-50 (mean age \pm SD: $33 \pm 6.51$ ) years who had been employed in the recycling and manufacture of automotive batteries in surroundings of coimbatore city (Tamilnadu). Of these workers, 14 (46.67) were smokers (no more than 20 cigarettes/day) and 16 (53.33) were non-smokers. The control groups consisted of 30 healthy male (83.33\%) and female (16.67\%) aged 20-50 (32.9 \pm 6.37$)$ years with no history of exposure to clastogenic and/or aneugenic agents and of socioeconomic level also similar to that of the subjects exposed to lead. Blood lead level also estimated in both control and experimental subjects.

At the time of blood collection ( $3 \mathrm{ml} /$ individual) the workers signed a term of informed consent and replied to a questionnaire elaborated to determine the profile and habits (age, time of work, salary, type of diet more commonly used, type of housing, use of drugs and medications, etc.) of the study population. The study procedures used in the present study were approved by the Institutional ethical committee.

\subsection{Sample collections}

Peripheral blood samples $(\mathrm{V}=5 \mathrm{ml})$ were collected under sterile conditions by venipuncture into heparinized tubes for comet assay (Singh, 1988).

Blood samples were collected into sodium-heparin Vacuette tubes for setting up vacutainers for determining the concentration of lead in the blood.

\subsection{Lead in blood (PbB) determination}

The levels of lead in whole blood were determined by electrothermal atomic absorption spectrophotometry according to Stoeppler and Brandt (1978). Vortex mixed blood $(200 \mu \mathrm{l})$ was added to $800 \mu \mathrm{l}$ of 5\% HNO3 in a pre-cleaned $2.2-\mathrm{ml}$ Eppendorf tube. The mixture was vortexed and left for $24 \mathrm{~h}$ in the refrigerator for better deproteinization. After centrifuging at $10000 \mathrm{rpm}$ for $15 \mathrm{~min}$, the supernatant was transferred to the Perkin-Elmer polystyrene autosampler cups. Then, $20 \mu \mathrm{l}$ of the solution was automatically injected into the pyro-coated graphite tube with a L'vov platform. Lead in the sample was vapourized at the optimized sequential dry-atomize transverse-heated graphite atomizer furnace programme developed in the laboratory. The atomic absorption signal of lead was measured in the absorbance-peak area mode using the Zeeman effect for background correction (Perkin-Elmer 4100ZL). The amount of lead in the blood samples was calculated by reference to matrix-matched calibration plots.

\subsection{Single cell gel electrophoresis (SCGE) assay}

The comet assay was conducted under alkali conditions according to Singh et al. (1988). All chemicals were obtained by Sigma. Two microlitre of whole blood were suspended in $0.5 \%$ low melting agarose and sandwiched between a layer of $0.6 \%$ normal melting agarose and a top layer of $0.5 \%$ low melting agarose on fully frosted slides. The slides were kept on ice during the polymerization of each gel-layer. After the solidification of $0.6 \%$ agarose layer the slides were immersed in lysis solution ( $1 \%$ sodium sarcosinate, $2.5 \mathrm{M} \mathrm{NaCl}, 100 \mathrm{mM}$ Na2EDTA, $10 \mathrm{mM}$ Tris- $\mathrm{HCl}, 1 \%$ Triton $\mathrm{X}-100$ and DMSO $10 \%)$ at $4{ }^{\circ} \mathrm{C}$. After $1 \mathrm{hr}$, the slides were placed in the electrophoresis buffer $(0.3 \mathrm{M} \mathrm{NaOH}, 1 \mathrm{mM}$ Na2EDTA, pH 10) for 20 min at room temperature to allow for DNA to unwind. The buffers were then chilled and the electrophoresis was performed at $300 \mathrm{~mA}$ and $19 \mathrm{~V}$ in a horizontal electrophoresis platform for 20 min. The slides were neutralized with Tris- $\mathrm{HCl}$ buffer $(\mathrm{pH} 7.5)$ and stained with $10 \%$ ethidium-bromide for 10 min. Each slide was analyzed by using Leitz Orthoplan epifluorescence microscope. For each subject 50 cells were analyzed by automatic digital analysis system Comet assay II (Perceptive Instruments Ltd., Suffolk, Halstead, UK), determining tail length and tail moment (tail length $\times$ tail $\%$ DNA/100). DNA damage was further quantified by visual classification of cells into categories of 'comets' corresponding to the amount of DNA in the tail according to Anderson et al. (1994).

\section{Statistical analysis}

All calculations were performed using MINITAB RELEASE II Software package for windows. Mean values and standard deviations (S.D.) were computed for the scores and the statistical significance (P/0.05) of effects (smoking) was determined using analysis of variance (ANOVA). Simple linear regression analyses were performed to assess the association between endpoints and independent variables.

\section{Results and discussion}

The effect of occupational exposure to $\mathrm{Pb}$, on the level of DNA damage in leucocytes of study group was assessed by the comet assay. A total 60 subjects corresponding to 30 experimental, and 30 controls were recruited for this study. With regard to serum $\mathrm{Pb}$ levels, experimental subjects showed maximum value of $5.28 \pm 0.25$, and control value was recorded as $3.28 \pm 0.64$ respectively. 
Table 1 and 2 represents the age, the number of smokers and years of exposure between the two groups involved in this study. The mean age of the control subjects was $32.9 \pm 6.37$ and that of experimental was $33 \pm 6.51$. The exposed groups displayed significantly higher levels of DNA damage than controls. The ranges of the MTL (mean tail length) and the MTM (mean tail moment) were $2.22 \pm 0.47 \mu \mathrm{m}$ and $0.76 \pm 0.26$ in workers, respectively, while the MTL and the MTM were $0.91 \pm 0.54 \mu \mathrm{m}$ and $0.31 \pm 0.45 \mathrm{in}$ controls, respectively. There was significant difference between workers and controls for MTL and MTM $(P<0.01)$.

Smoking exposure the lymphocytes of the exposed workers expressed higher DNA migration than of controls. The smokers had MTM $(0.71 \pm 0.27$ and 2.33 \pm 0.29$)$ and MTL than the non-smokers (0.70 \pm 0.26 and 2.25:0.34). Data shows a significant effect of Usage on MTL and MTM in the smokers. A significant increase of MTL and MTM in smokers was observed in the exposed workers. A clear and statistically significant increase in DNA migration was found in the study group when compared with the control groups as analyzed by ANOVA. Among the study group, significantly more were observed, the presence of cells demonstrating greater DNA damage than among control subjects

The present study indicates that workers occupationally exposed to $\mathrm{Pb}$, in the particular conditions of exposure of this collective evaluated, show clear evidence of genotoxic activity in their lymphocytes. These workers were not apparently exposed to other suspicious genotoxic agents at the workplace. Danadevi et al. (2003) detected a significant increase in DNA breaks in workers exposed to $\mathrm{Pb}$, as determined by the comet assay.

Although, environmental exposure to $\mathrm{Pb}$ has decreased considerably in countries that have banned leaded product, it is still a major environmental health problem in many countries that continue to use $\mathrm{Pb}$, or where people are exposed to deteriorated residential lead-based paint or Pb glazed ceramics used for storage and preparation of food (WHO, 1995). Lead readily passes the placenta, and the central nervous system is particularly sensitive during development (Lidsky and Schneider, 2003).

$\mathrm{Pb}$ is known to be a toxin affecting both the nervous and haematopoietic systems (Goyer, 1993). Its genotoxic potential has also been shown, although exact mechanisms are not explained (IARC 1980). $\mathrm{Pb}$ and inorganic $\mathrm{Pb}$ compounds are classified by International Agency for Research on Cancer in group 2B as possibly carcinogenic to humans. Our research revealed increased levels of $\mathrm{Pb}$ in blood concentration in the exposed group compared to the controls. Although, some studies indicated that gastrointestinal $\mathrm{Pb}$ absorption is enhanced at low body iron stores (Goyer, 1993), several recent studies speak against a common transport mechanism for iron and Pb (Bannon et al., 2003; Barany et al., 2005).

To our knowledge, there are three polymorphic genes identified that potentially can influence accumulation and toxicokinetics of $\mathrm{Pb}$ in humans. (Onalaja and Claudio, 2000).

The workers occupationally exposed to $\mathrm{Pb}$ were monitored in our investigation for genotoxic effects by the comet assay, the study group revealed a statistically significant increase in the level of DNA damage compared with the controls $(P<$ 0.01). The similar results were obtained in other investigations. The study of Danadevi et al. (2003) indicated that significantly more cells with DNA damage (44.58\%) were observed in the study group than in the controls (27.49\%).

It was observed in the investigation reported by Fracasso et al. (2002) that $\mathrm{Pb}$ exposed workers have significantly elevated levels of DNA breaks compared to the unexposed group. Similarly, Palus et al. (2003) found that the frequency of SCEs and the incidence of lymphocytes with DNA fragmentation in $\mathrm{Pb}$ exposed group were slightly, but significantly increased $(P<0.05)$ as compared with controls. Also the results were supported by some in vitro and animal experiments using comet assay (Wo'znika and Blasiak, 2003; Valverde et al., 2002; Devi et al., 2000). Valverde et al. (2002) carried out an experiment to explore the capacity of lead to interact with a cellular DNA, by employing a variant of the comet assay.

Smoking-related DNA adducts have been detected by a variety of analytical methods in the respiratory tract, urinary bladder, cervix and other tissues. In many studies the levels of carcinogen-DNA adducts have been shown to be higher in tissues of smokers than in tissues of nonsmokers (Nakayama et al., 1984). On terms of biological activity, cigarette smoke and its conductors have been shown to form adducts with DNA protein and to induce chromosome aberrations. Nakayama et al., (1985) reported DNA strand break in smokers due to the effect of electrophilic substances in tobacco. The "slower" response of peripheral lymphocytes of smokers as compared with non-smokers found in this analysis may be an expression of influence of $\mathrm{Pb}$ with cigarette smoke components on cellular immune response in man.

Although former cigarette smokers were more likely than those who had never smoked to have a smokeless tobacco lesion, we found little evidence for an independent effect of cigarette smoking and alcohol consumption on the presence of these lesions. (Balachandar et al., 2008; Sasikala et al., 2003). Jayakumar and Sasikala (2008) reported cigarette smoking routine has a synergistic effect on inducing DNA damage among the jewellery workers are occupationally exposed to nitric oxide.

DNA damage significantly increased with increase in years of exposure. Pinto et al. (2000) reported that cytogenetic damage in painters exposed to $\mathrm{Pb}$ was associated with occupational exposure time. Smoking had an insignificant effect 
on the level of DNA damage in the study group of our investigation. The lack of smoking influence on the comet assay results of this study could be due to less number of nonsmokers in the study group. These results agree with those presented by Fracasso et al. (2002), who found that smoking did not significantly affect comet assay values in $\mathrm{Pb}$ exposed workers.

In conclusion, even though the information available about the genotoxic and carcinogenic effects of Pb exposure are contradictory, the present results show that workers occupationally exposed to $\mathrm{Pb}$ showed a significantly higher DNA frequency in peripheral blood lymphocytes and smoking inhibits significant effect than controls. These observations support the need for preventive action that will improve conditions in the job environment and in micronutrient status since several studies have indicated that an increase in genotoxic effects is associated with an increased cancer risk.

\section{References}

Anderson, D., Yu TW., Phillips, B.J., Schmerzer, P. (1994). The effect of various antioxidants and other modifying agents on oxygen-radical-generated DNA damage in human lymphocytes in the comet assay. Mutat Res., 307: $291-298$.

Balachandar, V., Lakshman Kumar, B., Suresh, K., Manikantan, P., Sangeetha, R., Mohanadevi, S. (2008) Cytogenetic Damage in Khaini users of Tamilnadu, Southern India. Braz J Oral Sci., 7(25):1559-156.

Balachandar, V., Lakshmankumar, B., Suresh, K., Sasikala, K. (2008). Identification of chromosomal aberrations among Passive smokers of Tamilnadu, South India using Trypsin G-banding. Bull Environ Contam Toxicol., DOI 10.1007/s: 00128- 008-9489-3.

Barany, E., Bergdahl, I.A., Bratteby, L.E., Lundh, T., Samuelson, G., Skerfving, S.O., Skarsson, A. (2005). Iron status influences trace element levels in human blood and serum. Environ Res., 98: 215-223.

Danadevi, K., Rozati R.. Banu B.S., Rao, P.H., Grover, P. (2003). DNA damage in workers exposed to lead using comet assay. Toxicology, 187: 183-193.

Devi, K.D., Banu, B.S., Grover, P., Jamil, K. (2000). Genotoxic effect of lead on mice using SCGE(comet assay). Toxicology, 145: 195-201.

Devi, K.D., Saleha Banu, B., Grover, P., Jamil, K. (2000). Genotoxic effect of lead nitrate on mice using SCGE (comet assay). Toxicology, 145: 195-201.

Fracasso M.E., Perbellini L., Solda S., Talamini G., Franceschetti P. (2002). Lead induced DNA strand breaks in lymphocytes of exposed workers: role of reactive oxygen species and protein kinase C. Mutat Res., 515: $159-169$.

Fracasso, M.A., Perbellini, L., Solda, S., Talamini, G., Franceschetti, P. (2002). Lead induced DNA strand breaks in lymphocytes of exposed workers: role of reactive oxygen species and protein kinase C. Mutat Res., 515, $159-169$.

Goyer, R.A. (1993). Lead toxicity: current concerns. Environ Health Perspec, 100: 177-187.

Goyer, R.A. (1997). Toxic and essential metal interactions. Annu Rev Nutr. 17: 37-50. Bannon, D.I., Abounader, R., Lees, P.S., Bressler, J.P. (2003). Effect of DMT1 knockdown on iron, cadmium, and lead uptake in Caco-2 cells. Am J Physiol Cell Physiol, 284: C44-C50.

International Agency for Research on Cancer (IARC). (1980). Monographs on the Evaluation of Carcinogenic Risk of Chemicals to Humans Lead and Lead Compounds. Some Metals and Metallic Compounds, Vol. 23. IARC, Lyon, France, pp. 325-415.

Jayakumar, R., Sasikala, K. (2008). Evaluation of DNA damage in jewellery workers occupationally exposed to nitric oxide. Environ Toxi pharmacol, 26(2): 259-261.

Johnson, F.M. (1998). The genetic effects of environmental lead. Mutat Res., 410: 123-140.

Lanphear, B. P., Dietrich, K., Auinger, P. and Cox, C. (2000). Cognitive deficits associated with blood lead concentrations, 10lg/dl in US children and adolescents. Public Health Rep., 115: 521-529.

Lidsky, T.I., Schneider, J.S. (2003). Lead neurotoxicity in children: basic mechanisms and clinical correlates. Brain, 126: 5-19.

Maluf, S.M., Erdtmann,B. (2000a). Evaluation of occupational genotoxic risk in a Brazilian hospital. Genetics and Molecular Biology, 23: 485-488.

Maluf, S.M., Erdtmann,B. (2000b). Follow-up study of genetic damage in lymphocytes of pharmacists and nurses handling antineoplastics drugs evaluated by cytokinesis-block micronuclei analysis and single cell gel electrophoresis assay. Mutation Research, 471: 21-27.

Mielzyn'ska, D., Siwin'ska, E. and Kapka, L. (2001). Mutagenicity of airborne particles as an indicator of air quality. Institute of Occupational Medicine and Environmental Health, ISBN-83-909595-6-7, Part A. Report to the National Fund of Environmental Protection. 
Nakayama T., Kaneko M., Kodama M., Nagata C. (1985). Cigarette smoke induces DNA single-strand breaks in human cells. Nature (Lond.), 314: 462-464.

Nakayama T., Kodama M., Nagata C. (1984). Generation of hydrogen peroxide and superoxide anion radical from cigarette smoke. Gann, 75: 95-98.

Onalaja, A.O., Claudio, L. (2000). Genetic susceptibility to lead poisoning. Environ. Health Perspect, 108 (Suppl. 1): 23-28.

Palus, J., Rydzynski, K., Dziubaltowska, E. Wyszynska, K., Natarajan, A. T., R. Nilsson. (2003). Genotoxic effects of occupational exposure to lead and cadmium. Mutat Res., 540: 19-28.

Pinto, D., Ceballos, J.M., Garcia, G., Guzman, P., Del Razo, L.M., Vera, E., Gomez, H., Garcia, A., Gonsebatt, M.E. (2000). Increased cytogenetic damage in outdoor painters. Mutat Res., 467: 105-111.

Sasikala, K., Regina Rosalin, F., Calistus Jude, A.L., Ashok Kumar, R., Sudha, S., Vimala Devi, M., Balachandar, N., Sajeetha Beegam, K.A., Meenakshi, N., Asia Begum. (2003). Active and Passive Smokers - A Haematobiochemical and Cytogenetic Study. Int J Hum Genet. 3(1): 29-32.

Singh, N.P., McCoy, M.T., Tice, R.R., Schneider, E.L. (1988). A simple technique for quantitation of low levels of DNA damage in individual cells. Exp Cell Res., 175:184-191.

Stoeppler, M., and Brandt, K. (1978). Contributions to automated trace analysis. Part II. Rapid method for the automated determination of lead in whole blood by electrothermal atomic-absorption spectrophotometry. Analyst, 103: 714-722.

Vaglenov, A., Creus, A., Laltchev, S., Pavlova, V., Marcos, R. (2001). Occupational exposure to lead and induction of genetic damage. Environ Health Perspect, 109: 295-298.

Valverde, M., Fortoul, T.I., Diaz-Barriga, F., Mej'1a, J., del Castillo, E.R. (2002). Genotoxicity induced in CD1-mice by inhaled lead: differential organ response. Mutagenesis, 17: 55-61.

WHO. (1995). Inorganic Lead: Environmental Health Criteria, vol. 165. International Programme on Chemical Safety, World Health Organization, Geneva.

Wo'znika, K., Blasiak, J. (2003). In vitro genotoxicity of lead acetate: induction of single and double DNA strand breaks and DNAprotein cross-links. Mutat Res., 535: 127-139. 
Table 1. Data showing the general characteristics of control subjects

\begin{tabular}{|c|c|c|c|c|c|}
\hline Controls & Sex & Age & $\mathrm{PbB}(\mu \mathrm{g} / \mathrm{dl})$ & $\operatorname{MTL}(\mu \mathrm{m})$ & MTM \\
\hline 1 & M & 32 & 3.45 & 0.96 & 0.49 \\
\hline 2 & M & 28 & 3.69 & 1.29 & 0.14 \\
\hline 3 & M & 23 & 3.16 & 1.36 & 2.47 \\
\hline 4 & M & 27 & 3.47 & 1.45 & 0.98 \\
\hline 5 & M & 41 & 3.43 & 1.18 & 0.39 \\
\hline 6 & M & 38 & 3.47 & 0.29 & 0.21 \\
\hline 7 & M & 26 & 3.43 & 0.89 & 0.15 \\
\hline 8 & M & 41 & 3.24 & 0.90 & 0.26 \\
\hline 9 & M & 33 & 3.42 & 0.81 & 0.61 \\
\hline 10 & M & 39 & 3.39 & 0.77 & 0.13 \\
\hline 11 & $\mathrm{~F}$ & 29 & 2.78 & 0.34 & 0.16 \\
\hline 12 & M & 26 & 3.21 & 0.77 & 0.16 \\
\hline 13 & M & 43 & 3.06 & 1.03 & 0.24 \\
\hline 14 & M & 29 & 3.17 & 3.39 & 0.13 \\
\hline 15 & M & 35 & 3.41 & 0.71 & 0.17 \\
\hline 16 & M & 26 & 3.18 & 0.91 & 0.17 \\
\hline 17 & M & 32 & 3.01 & 0.74 & 0.16 \\
\hline 18 & $\mathrm{~F}$ & 42 & 3.12 & 0.62 & 0.14 \\
\hline 19 & M & 30 & 3.28 & 0.96 & 0.18 \\
\hline 20 & M & 25 & 3.24 & 0.87 & 0.19 \\
\hline 21 & M & 31 & 2.87 & 0.74 & 0.25 \\
\hline 22 & M & 45 & 3.15 & 0.95 & 0.17 \\
\hline 23 & $\mathrm{~F}$ & 32 & 3.75 & 0.49 & 0.14 \\
\hline 24 & M & 27 & 3.29 & 0.90 & 0.14 \\
\hline 25 & M & 37 & 3.32 & 0.78 & 0.15 \\
\hline 26 & $\mathrm{M}$ & 44 & 3.26 & 0.92 & 0.17 \\
\hline 27 & $\mathrm{M}$ & 28 & 3.41 & 0.71 & 0.23 \\
\hline 28 & $\mathrm{~F}$ & 30 & 3.32 & 0.43 & 0.17 \\
\hline 29 & $\mathrm{~F}$ & 30 & 3.34 & 0.74 & 0.29 \\
\hline 30 & M & 38 & 3.75 & 0.62 & 0.35 \\
\hline
\end{tabular}

F, female; M, male; MTL, mean tail length; MTM, mean tail moment; PbB, Blood lead level. 
Table 2. Showing the Blood lead level and DNA damage in experimental subjects

\begin{tabular}{|c|c|c|c|c|c|c|c|c|}
\hline Workers & Sex & Age & Sex & Smoking & $\begin{array}{c}\text { Exposure } \\
\text { Period (yrs) }\end{array}$ & $\mathrm{PbB}(\mu \mathrm{g} / \mathrm{dl})$ & MTL $(\mu \mathrm{m})$ & MTM \\
\hline 1 & $\mathrm{M}$ & 32 & M & $\mathrm{S}$ & 4 & 5.29 & 2.52 & 0.67 \\
\hline 2 & $\mathrm{M}$ & 28 & $\mathrm{M}$ & NS & 2 & 5.42 & 1.51 & 0.69 \\
\hline 3 & $\mathrm{M}$ & 24 & $\mathrm{M}$ & NS & 3 & 5.28 & 2.01 & 0.62 \\
\hline 4 & $\mathrm{M}$ & 27 & $\mathrm{M}$ & $\mathrm{S}$ & 3 & 5.39 & 1.94 & 0.40 \\
\hline 5 & $\mathrm{M}$ & 41 & M & $\mathrm{S}$ & 3 & 5.17 & 2.43 & 0.53 \\
\hline 6 & M & 38 & M & NS & 3 & 5.42 & 1.88 & 0.48 \\
\hline 7 & M & 25 & M & NS & 3.5 & 5.81 & 1.84 & 0.82 \\
\hline 8 & M & 42 & M & NS & 2 & 5.26 & 2.28 & 0.73 \\
\hline 9 & $\mathrm{M}$ & 33 & M & $\mathrm{S}$ & 2 & 4.87 & 2.09 & 1.24 \\
\hline 10 & $\mathrm{M}$ & 39 & $\mathrm{M}$ & NS & 3 & 5.55 & 1.58 & 0.76 \\
\hline 11 & $\mathrm{~F}$ & 28 & $\mathrm{~F}$ & NS & 2.5 & 5.23 & 2.77 & 1.05 \\
\hline 12 & M & 27 & M & $\mathrm{S}$ & 3 & 5.12 & 2.19 & 0.98 \\
\hline 13 & M & 43 & M & NS & 2 & 5.03 & 1.66 & 0.65 \\
\hline 14 & $\mathrm{M}$ & 29 & M & $\mathrm{S}$ & 2.5 & 5.08 & 2.76 & 0.49 \\
\hline 15 & $\mathrm{M}$ & 35 & M & NS & 3 & 5.06 & 3.43 & 0.79 \\
\hline 16 & $\mathrm{M}$ & 26 & M & $\mathrm{S}$ & 3 & 5.20 & 2.16 & 0.55 \\
\hline 17 & $\mathrm{M}$ & 32 & $\mathrm{M}$ & NS & 3.5 & 5.01 & 3.02 & 0.39 \\
\hline 18 & $\mathrm{~F}$ & 41 & $\mathrm{~F}$ & NS & 4 & 5.63 & 2.32 & 0.74 \\
\hline 19 & $\mathrm{M}$ & 29 & M & $\mathrm{S}$ & 3 & 5.21 & 2.47 & 1.15 \\
\hline 20 & $\mathrm{M}$ & 25 & $\mathrm{M}$ & $\mathrm{S}$ & 2.5 & 5.01 & 2.06 & 0.53 \\
\hline 21 & $\mathrm{M}$ & 31 & $\mathrm{M}$ & $\mathrm{S}$ & 4 & 5.09 & 2.48 & 0.76 \\
\hline 22 & $\mathrm{M}$ & 46 & $\mathrm{M}$ & $\mathrm{S}$ & 3 & 5.42 & 2.68 & 0.77 \\
\hline 23 & $\mathrm{~F}$ & 31 & $\mathrm{~F}$ & NS & 2.5 & 5.62 & 1.57 & 0.58 \\
\hline 24 & M & 27 & M & $\mathrm{S}$ & 2 & 5.42 & 2.51 & 0.86 \\
\hline 25 & M & 37 & M & NS & 2.5 & 5.68 & 2.27 & 1.31 \\
\hline 26 & $\mathrm{M}$ & 45 & M & $\mathrm{S}$ & 4.5 & 5.81 & 2.52 & 0.45 \\
\hline 27 & $\mathrm{M}$ & 29 & $\mathrm{M}$ & NS & 3.5 & 4.99 & 2.13 & 1.35 \\
\hline 28 & $\mathrm{~F}$ & 31 & $\mathrm{~F}$ & NS & 4 & 5.05 & 2.49 & 0.78 \\
\hline 29 & $\mathrm{~F}$ & 30 & $\mathrm{~F}$ & NS & 2 & 5.01 & 1.32 & 1.07 \\
\hline 30 & $\mathrm{M}$ & 39 & $\mathrm{M}$ & $\mathrm{S}$ & 3.5 & 6.10 & 1.82 & 0.63 \\
\hline
\end{tabular}

F, female; M, male; MTL, mean tail length; MTM, mean tail moment; PbB, Blood lead level. 


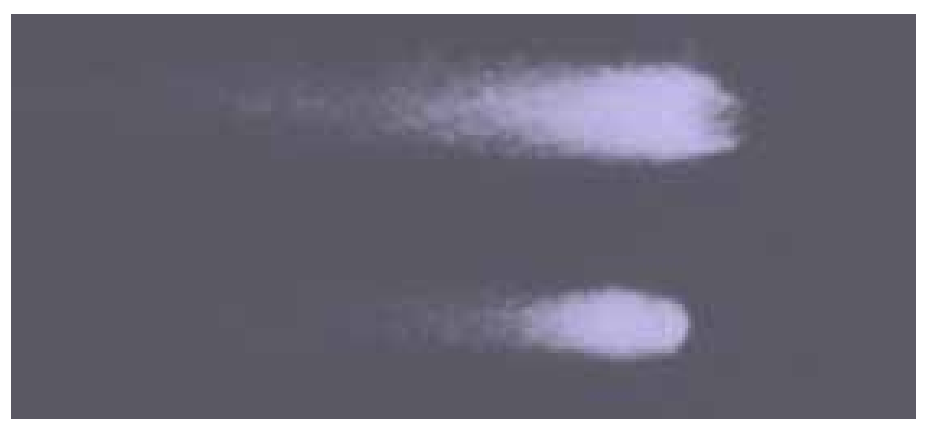

Figure 1. Experimental subjects

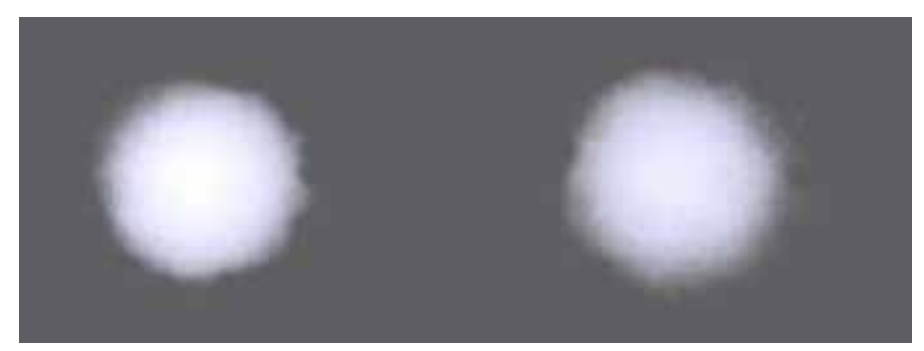

Figure 2. Control subjects 